\title{
THE EFFECT OF GROUP INVESTIGATION AND LEARNING STYLE ON STUDENTS' WRITING OF ANALYTICAL EXPOSITION
}

\author{
Bambang Untoro \\ Al-Azhar University, Indonesia \\ (bambanguntoro@yahoo.com)
}

\author{
Received: $24^{\text {th }}$ March 2016; Revised: $22^{\text {th }}$ April 2016; Accepted: $25^{\text {th }}$ June 2016
}

\section{ABSTRACT}

This study aimed to investigate the influence of group investigation, the difference between auditory and visual students, and the interaction between group investigation and learning style on students' writing of analytical exposition. It was a quasi-experimental conducted for the second graders of SMA Islam Al-Azhar BSD. The findings revealed that there was an influence of group investigation on students' writing of analytical exposition. The writing of students that experienced the group investigation model was better than those who had the conventional one. There was a significant difference between auditory students and visual students on their writing of analytical exposition. In both groups, the visual students had better achievement than the auditory ones. However, the visual and auditory students in experimental group had higher improvement. There was also a significant interaction between group investigation and learning style on students' writing of analytical exposition. It could be concluded that applying a group investigation model was recommended in teaching writing of analytical exposition.

Key Words: group investigation; writing; analytical exposition; learning style

\section{ABSTRAK}

Penelitian ini bertujuan untuk menyelidiki pengaruh model pembelajaran investigasi kelompok, perbedaan antara siswa bergaya belajar audio dan visual, dan interaksi antara model investigasi kelompok dan gaya belajar terhadap kemampuan menulis analytical exposition siswa. Penelitian ini merupakan eksperimen semu yang dilakukan pada siswa kelas XI SMA Islam Al-Azhar BSD. Hasil penelitian menunjukkan bahwa terdapat pengaruh yang signifikan antara siswa yang diajarkan melalui investigasi kelompok dengan siwa yang diajarkan secara konvensional, terdapat perbedaan yang signifikan antara siswa bergaya belajar audio dengan siswa bergaya belajar visual. Siswa visual cenderung berkemampuan menulis lebih bagus daripada siswa audio. Namun, ditinjau dari kedua gaya belajar tersebut, siswa pada kelas eksperimen berkemampuan menulis lebih bagus daripada siswa pada kelompok kontrol. Terdapat interaksi yang signifikan antara investigasi kelompok dan gaya belajar terhadap kemampuan menulis siswa. Hasil penelitian ini menyimpulkan bahwa model pembelajaran investigasi kelompok sesuai untuk pengajaran menulis analytical exposition.

Kata kunci: investigasi kelompok; menulis; analytical exposition; gaya belajar

How to Cite: Untoro, B. (2016). The Effect of Group Investigation and Learning Style on Students' Writing of Analytical Exposition. IJEE (Indonesian Journal of English Education), 3(1), 29-45. doi:10.15408/ijee.v3i1.3445

Permalink/DOI: http://dx.doi.org/10.15408/ijee.v3i1.3445 


\section{INTRODUCTION}

English plays an important role in education and other environments related to its function as a means of communication. Consequently, many educational institutions both formal and informal include English subject to teach. Related to the formal education, English is a compulsory subject in higher levels of education, including senior high schools.

In learning English, writing is one of the language skills which need to be mastered by the learners. It is underlined by Harmer (2004) who states that writing is one of the four skills that should be mastered by students and has always formed part of the syllabus in the teaching of English. In senior high schools, students have to learn different genres of writing like narrative, descriptive, and argumentative based on the prescribed syllabus from the Ministry of Education. Mastering writing skill is very essential as it is used especially after students graduate and are involved in their work fields.

The teaching and learning activity of writing is one of the matters that needs to be underlined since it is often conducted uninterestingly so that the students feel reluctant and do not have motivation to learn the materials. The teaching and learning process of argumentative writing is also often conducted conventionally in which the teacher provides a certain topic verbally that often makes students difficult to construct their ideas. Teachers often pay more attention to the students' final essays. This also happens in SMA AlAzhar BSD as the context of the study, in which the teacher emphasizes on the result of the students' essay. Concerning the basic competencies that the students have to achieve, many students of SMA Islam Al-Azhar BSD still find it difficult to write analytical exposition essay. From the preliminary study, the researcher got the data of students' English essays in which the average score is still low.

Group Investigation is one of effective ways to improve students' writing skill. It allows a class to work actively and cooperatively in small groups and enables students to take an active role in determining their own learning goals and processes. Group Investigation is expected to help students think critically by elaborating their ideas, opinion, and arguments to solve certain issues or problems. The students are expect to have experiences in identifying the topic, planning the investigation, carrying out investigation, preparing a final report, presenting it, and evaluating 
achievement (Slavin, 2005). These activities are very essential in developing students' writing skill, especially the writing of analytical exposition.

In learning, there are several factors which affect student outcome, one of which is students' learning characteristics or learning styles. Ideally, students have to realize that they hold a dominant style in learning which is different from others. Maximizing this style is necessary to optimize their learning process. Brown (2007, p. 129) states that the dimension of learning style that is salient in a formal classroom setting is the preference that students or learners show toward either visual, auditory, and kinesthetic input. However, from the three dimensions, visual and auditory learning styles are believed to be more dominant in the process of writing activities. Sutrisno, et.al. (2013, p. 157) prove in their research that visual and auditory learning style influence the students' writing. Therefore, this study focuses on the visual and auditory learning style.

Writing activity is not simple since a person should think several subskills such as the mastery of the language itself, the knowledge of the related topic, and the way how to express ideas into written form.
Mastering writing skill is very essential as it is used even after students graduate and involve in their work fields. Functional writing forms, such as business letters, advertisements, manual books, brochures, and others, will be their daily tasks when people work. Nunan (1998, p. 37) claims that success in writing should involve six aspects: mastery of writing techniques, controlled and adherence to the conventions of spelling and punctuation usage, the use of grammar system to convey the intention/meaning of a person, the ability to organize the contents of the full text to provide a written description of the information, revise writing, and to select and customize the style needs of readers. This shows the complexity of thought that needs to be mastered by a competence writer in producing a quality essay.

Writing is a process which needs several steps. However, there are still some learners who ignore this process. They only write once without paying attention to the process. Consequently, their writing often still has some errors related to either the content or the grammar. Mastery of a number of aspects can be used as a means of assessment of the activity of writing. Hung and Young (2015, p. 250) underlines that writing process consists 
of prewriting, writing, revising, editing, and publishing.

A good essay does not merely have good grammar and sentence patterns or even good vocabularies, but involves other important aspects. Therefore, teachers need to work hard effort to motivate and encourage learners to write. Implementing a cooperative learning like group investigation model is one way to create a competitive and motivational learning process to improve the learners' mastery of writing skill especially an argumentative one since it needs some ideas and arguments that sometimes can be found and elaborated through discussion lead by the teacher.

Based on the aspects involved in the writing process, learners can have low motivation if there is no trigger from the teachers. It is generally known that teachers play important roles in determining the success of learners in improving their writing achievement. Further, various approaches are adopted to make teaching writing interesting and effective. Khatijah (as cited in Syafini \& Rizan, 2012, p. 407) proposes two approaches that teachers can adopt in teaching writing: the product approach and the process approach.

The first approach is the product approach which focuses on the end result of the act of writing. It emphasizes on the different part of the text, words, sentences, paragraphs but there is not much focus on ideas and meaning (Zamel, as cited in Syafini \& Rizan, 2012, p. 407). The role of the teacher is to examine the finished product focusing more on linguistic accuracy (McDonough \& Shaw, as cited in Syafini \& Rizan, 2012, p. 407). Since it focuses on the final result of students' writing, the students do not have an opportunity to have the feedback to improve their essays. Flower and Hayes (as cited in White, 1988) believe that this approach is insufficient in enhancing the students' writing performance.

The second approach to writing is the process approach which focuses on how learners actually write. Kroll (as cited in Akhand and Hasan, 2010, p. 79) describes that the process approach serves today as an umbrella term for many types of writing courses. They are not expected to produce and submit complete and polished responses to their writing assignments without going through stages of drafting and receiving feedback on their drafts, be it from peers and/or from the teacher, followed by revision of their evolving texts. Thus, writing is a process which needs variety of learning activities. A process approach tends to focus more 
on varied classroom activities which promote the development of language use: brainstorming, group discussion and rewriting (Akhand and Hasan, ibid).

Writing also needs some sub skills like understanding how to explore the contents of the idea, understanding essay organization, mastering vocabulary, mastering language knowledge, and understanding the mechanics. In writing, students have to consider what to write and how to write (Jacobs et. al, as cited in Weigle, 2002). Once students want to write, they have to choose a topic, then extent the idea in order to know what is actually elaborated. However, how to write will guide the writer of how to express the idea of the writing which can be an argument, narration, description or other kinds of writing (Ernidawati and Sianturi, 2012, p. 2). Through writing the students can transfer their experiences and knowledge to other. So, they should be able to produce sentence and develop it into paragraph, essay, and paper.

However, many teachers still find it difficult to teach their students how to writing effectively. There are still some constraints faced by them in guiding their students to be actively involved during the teaching and learning process. Some of the teaching and learning activities designed may not run smoothly because there are some complex problems during the process, such as students' lack of English grammar and vocabulary, students' knowledge of the topic itself, students' learning styles, students' motivation, the class condition, and others.

In analytical exposition as the focus of the study, there should be a topic which is necessary to be discussed. The topic is usually related to the recent and important problems happen and need to be explored. In doing so, it is not easy for there are still several students who are not familiar with the problems. Therefore, they do not know what to write. Therefore, the teacher should try to guide them to explore the problem by implementing, for example, a group investigation model. Conducting writing activities in group is effective because students can have higher motivation and elaborate the topic by working actively and cooperatively (Harmer, 2004).

There are many strategies or teaching and learning methods that will help the teacher in teaching English, especially in teaching writing. One of the strategies that can help enhancing the students' writing of analytical exposition is applying a group investigation model. Group investigation, according to Isjoni (2009) 
is an organizational approach that allows a class to work actively and cooperatively in small groups and enables students to take an active role in determining their own learning goals and processes. Group investigation method requires the students to form small interest groups, plan and implement their investigation, synthesize the group members' findings, and make a presentation to the entire class. This model requires the students to take roles in searching sources, investigating relevant materials, proposing arguments, and presenting them within their groups and to the class.

Furthermore, Slavin (2005, p. 218), explains six stages in conducting a group investigation. Stage 1 is identifying the topic and organizing into research group; Stage 2 is planning the investigation in groups; Stage 3 is carrying out the investigation; Stage 4 is preparing a final report; Stage 5 is presenting the final report; Stage 6 is evaluating achievement. It is assumed that this model positively effects the students' writing of analytical exposition.

However, every single learner has his/her own style of learning, including the learning of writing. Some learners are good at visual activities. These learners will maximize their eyes in receiving and processing information, such as pictures, graphics, diagrams, photographs, and other visual media. Others may use their ears during the learning process. Auditory learners will learn fast through verbal discussion and listen to teacher's explanation. There are also many students who prefer moving, touching, and practicing during the learning process. The term "Learning Style" has been defined by various scholars mostly as a signal for individual differences. Honey and Mumford (as cited in Singh, et.al., 2011, p. 144) describe learning style as an individual preference or habitual ways of processing and transforming knowledge. Learning style is the combination of how someone absorbs and manages information (DePorter \& Hernacki, 2007). While Keefe (as cited in Brown, 2007, p. 120) emphasizes learning styles as cognitive, affective, and psychological traits that serve as relatively stable indicators of how learners perceive, interact with, and respond to the learning environment. Besides, Pasher, et.al. (2009, p. 105) emphasize that learning style refers to the concept that individual differ regarding to what mode of instruction or study is most effective for them. Since learners differ in their preferences to certain learning styles, it will be important for teachers to examine the variations in their students on the 
features of their learning styles, because the information about learner's preference can help teachers become more sensitive to the differences students bring to the classroom (Felder \& Purlin, 2005, p. 103). Thus, adjustments can then be made to accommodate the students' varied needs.

This study hypothesizes that the students' who get group investigation during the teaching and learning process will have higher skill in writing analytical exposition. During the teaching and learning activities of writing analytical exposition, they have the experience of planning, constructing, revising, and publishing or communicating their writing through investigation. Besides, they also have different way in receiving information. Although students have the same treatment, they still tend to dominantly apply a certain learning style which is comfortable for them. Visual and auditory learners have different way in receiving and processing information during the learning process. In other words, applying group investigation model is not the only variable which can affect the students' writing of analytical exposition. The students' learning style is also another variable that can give effect to their achievement of writing.
Therefore, this study also incorporates learning style as an independent variable, together with the intervention.

\section{METHOD \\ Design}

This was a quasi-experimental study employing a pre-test and posttest. This study has an independent variable with two dimensions: Group Investigation model (GI) and conventional learning model $(\mathrm{CV})$. It also has an attributive or moderator variable: learning styles, which is divided into visual and auditory learning style. The dependent variable of this research is the writing of analytical exposition. Thus, this research is conducted using $2 \times 2$ factorial design with pre-test post-test groups.

\section{Participants}

The population was the second grade students of SMA Islam Al-Azhar BSD in Academic Year of 2015-2016. There were six classes in this grade with around thirty students for each class, so there were 180 students altogether. The six classes were divided into 2 programs: mathematics and natural science program (MIPA) and social science program (IPS). There were three classes for natural science program and three other classes for social science 
program. The school required some considerations in determining the class, such as students' intelligence, average scores from their report book, attitudes, and gender.

In determining the sample, the researcher chose two classes randomly from available class. He got two classes: XI MIPA 1 and XI MIPA 3. Then, from the two sample classes, he chose randomly to determine the class for experiment. Finally, he got XI MIPA 3 as the experiment group.

\section{Instruments}

There are two kinds of instruments used in this research. The first instrument was a questionnaire to get the data of students' learning style. This instrument was administered in both the controlled class and the experimental class before the treatment. The second instrument was a writing test to measure the students' writing ability of analytical exposition which was administered also in both groups. This test was conducted before and after the students got the treatment. The elements of the composition measured are based on ESL Composition Profile developed by Jacobset.al. These elements include the content, organization, vocabulary, language use, and mechanics. (Jacobs et. al, as cited in Weigle, 2002, p. 115).
Before administering the research instruments, the researcher had to test their validity and reliability. Because the writing test instrument is considered as valid and reliable (Weigle, 2002, p. 120-121), the researcher just conducted a try-out of learning style instrument. It was administered to 30 students. The data was analyzed statistically applying $r$ Pearson Product Moment and Alpha Cronbach formula.

\section{The Content of Intervention}

This study was conducted in ten meetings. The first one was conducted to administer a questionnaire to get the data of students' learning styles and the pre-test for the analytical exposition essay. In doing so, the researcher gave one of the instruments, a questionnaire of learning style, to the controlled class and experimental class. They had to answer the 20 questions which took around 10 minutes. After that, the pretest was administered to measure the students' prior writing ability of analytical exposition. This test was conducted to both groups before any treatment. They were asked to write an essay of analytical exposition in around 40 minutes. Then, the researcher discussed with the teacher the preparation of implementing group investigation in the experimental group. It included the lesson plan, the 
materials, and other preparation needed. The next eight meetings were allotted for the implementation of group investigation. It had six stages proposed by Slavin (2005) which included identifying the topic and organizing into research group, planning the investigation in group, carrying out investigation, preparing a final report, presenting the final report, and evaluating achievement. Finally, the last meeting was used to administer the post test of writing an analytical exposition. It was conducted to measure the students' writing ability after the treatment finished.

\section{Data Analysis}

The data were analyzed to know whether there was a significant effect of group investigation model to the writing of analytical exposition. The researcher also analyzed the data of the students' learning style to know whether there was also an effect of the learning style to the students' writing of analytical exposition. Besides, the researcher also analyzed all the data to know whether there was a significant interactional effect of group investigation model and learning styles to the students' writing of analytical exposition.

The data collected were also analyzed descriptively to find the mean, median, modus, variance, and standard deviation. In answering the research questions, two-way Analysis of Variance (ANAVA) with the significance of $(\alpha)=0.05$ was employed to examine the effect of group investigation model to students' writing of analytical exposition viewed from their learning style. This analysis means that if the significance coefficient value of the variable is less than $0.05(<0.05)$, $H_{0}$ is rejected, and $H_{1}$ is accepted. The output of this variance analysis with the factorial design of $2 \times 2$ was used to prove the three proposed research hypotheses. Necessary preliminary analyses such as normality and homogeneity of data were conducted, which results revealed that the data were both normal and homogeny.

\section{FINDINGS AND DISCUSSION Findings}

The descriptive data showed the results of pre-test and post-test of students' writing of analytical exposition both in the controlled class and the experimental class. Based on the data of the pretest score of writing analytical exposition in the controlled class, it was found that the mean was 59.33, the median was 58.50, the standard deviation was 8.07. Furthermore, the minimum score was 57 while the maximum score was 77 . 
The mean of the students' achievement in writing analytical exposition was still low for the minimum criteria determined by the school was 75.00 . The mean score of the experimental class was also low, which was 59.90 with a standard deviation of 7.90. The minimum score was 44 and the maximum score was 78 .

After the treatment, differences between the experimental and controlled class appeared. The mean score of the post-test score in the controlled was 69.57 while that of the experimental class was 81.32. Although we could see improvement in the controlled class, it was still below the minimum criteria of 75.00 determined by the school. In the controlled class, there were still 22 students (73.33\%) who got less than 75.00, and only 8 students $(26.67 \%)$ who could achieve 75 or more.

Further, based on the post-test scores in the experimental class, the minimum score was 63 and the maximum score was 93 . If the mean from the post-test here is compared to the mean from the pre-test, there was an improvement from 59.90 to 81.32 . The achievement of 81.32 was above the minimum criteria of 75.00 determined by the school. There were only 5 students $(16.1 \%)$ who got less than 75.00 , and amazingly there were 26 students $(83.9 \%)$ who could achieve 75 or more. This achievement indicated that there was an effect of group investigation model to the students' writing of analytical exposition.

The data analysis also showed that visual learners had higher achievement in their writing of analytical exposition than auditory learners. It means that visual learners tended to have better achievement in their writing of analytical exposition than auditory learners. Both visual and auditory learners in experimental class had higher achievement in their writing of analytical exposition than those in controlled class. In other words, using group investigation model in teaching writing of analytical exposition was able to enhance the students' writing.

Table 1. The Improvement of Students'

Writing in Controlled Class and Experiment Class

\begin{tabular}{llll}
\hline Group & Mean & & \\
\cline { 2 - 4 } & $\begin{array}{l}\text { Pre- } \\
\text { Test }\end{array}$ & $\begin{array}{l}\text { Post- } \\
\text { Test }\end{array}$ & $\begin{array}{l}\text { Improv } \\
\text { ement }\end{array}$ \\
$\begin{array}{l}\text { Controlled } \\
\text { Class }\end{array}$ & 59.33 & 69.57 & 10.24 \\
$\begin{array}{l}\text { Experiment } \\
\text { Class }\end{array}$ & 59.90 & 81.32 & 21.42 \\
\hline
\end{tabular}

The mean of the writing achievement in the controlled class was 69.57, whereas the means of the writing achievement in the experimental class was 81.32 . When it is compared to the 
result of the pre-test scores, both classes had an improvement, but the experimental class had higher improvement than that in the controlled class with the difference of 11.75 points in the mean score.

After delivering the instrument of learning style to the 30 students in the controlled class, there are 15 students holding visual learning style and 15 students having a tendency of auditory learning style. The average post test score of the visual students is 70.80 , and the average score of auditory students is 68.33. Then, from the 31 students in the experimental class, 18 students hold visual learning style and the other 13 students have a tendency of auditory learning style. The average post test score of the visual students is 85.67 , and the average score of auditory students is 75.31 .

The first result of the data analysis described that the significance value of Group Investigation model was 0.000 . There was a significant difference between the students taught by group investigation and those taught conventionally on their writing of analytical exposition. It can be concluded that the writing of analytical exposition for students who were taught by group investigation model was better than the writing of analytical exposition of those taught conventionally. Group investigation model was proved to give significant effect of the students' achievement in writing of analytical exposition.

The second result of the data analysis showed that the significance value of the learning style was 0.000 . It means that there was a significant difference between auditory students and visual students on their writing of analytical exposition.

The third analysis described that the significance value of the learning style and group investigation model was 0.019 . Based on the data analysis, there was a significant interaction between group investigation model and learning styles to students' writing of analytical exposition.

The extended test was performed to find out which group contributed more to the students' writing according to the teaching model and learning style. The test was conducted using the contrast test with t-test statistic. From the analysis result, it was obtained that the value of significance from GI Vis (A1B1) $>C$ CV Vis (A2B1) was 0.002 . Since the value of significance was less than $0.05(0.002<0.05)$, it means that there was a significant difference between visual students taught by Group Investigation model and those taught conventionally on their writing of analytical exposition. Further, it was 
also obtained that the value of significance from GIAud (A1B2) $><C V$ Aud (A2B2) was less than $0.05(0.002<$ $0.05)$. It means that there was a significant difference between auditory students taught by Group Investigation model and those taught conventionally on their writing of analytical exposition.

Further analysis described clearly that the writing achievement of visual learners was higher than that of auditory learners. They can learn faster when there are some visual illustrations like diagram, video, and other fullpicture books. Besides, they like to make some notes in detail. Writing activity gave opportunities for students to make some notes. Further, in group investigation model, the students used more visual illustrations like diagram, video, and other full-picture books when they investigated using some related sources.

\section{Discussion}

The findings of the pre-test and post-test of the writing showed that the students performed better in the posttest compared to the pre-test. They had gained better achievement in their writing of analytical exposition. This significant improvement proved that the incorporation of group investigation model had positive outcomes in enhancing the students' writing performance, especially in writing of analytical exposition. It proved that the inclusion of group investigation model in the writing lessons, especially the writing of analytical exposition, had positive effects on the students' improvement in all the five writing components which were important to produce better essays. It is in line with the previous research conducted by Pitoyo (2014) which revealed that the writing skills of students who followed the group cooperative learning model in the type of Group Investigation was better than the group of students who learnt through Accelerated Learning Team and Role Playing. He concluded that applying group investigation model in teaching the students was effective to help the students in improving their writing skill. The incorporation of group investigation model as one type of a cooperative learning gave more opportunity for the students to explore their ideas during the process of their learning. This research finding also supported the previous research conducted by Syafini and Rizan (2012) which revealed that there were positive effects of cooperative learning in enhancing writing performance. The findings indicated that the students perform better in the post-test compared with the pre-test after the inclusion of 
cooperative learning in the writing classes.

The finding of this research describes that there was a significant difference between auditory students and visual students on their writing of analytical exposition. It showed that the visual learners had higher achievement in their writing of analytical exposition. They performed better achievement especially in their writing of analytical exposition than auditory learners. It is in line with the theory proposed by Studer (2015, P. 300-301) who states that visual learners like to learn through written language, such as reading and writing tasks, whereas auditory learners tend to have difficulty with reading and writing tasks. The way how auditory learners received information or learning materials was different from the way how visual learners received them. They will optimize their own style so that they can maximize their learning mastery. It is in line with the previous research conducted by Ahmed (2012) which revealed the effect of different learning styles on developing writing of English as a Foreign Language (EFL). In this research, the students were taught regardless of their different learning styles. It was found that the students experienced some writing difficulties. Then, he conducted an experiment by giving a learning style inventory to the experimental group to help the students as well as their teacher be aware of their learning styles.

Further finding of this research also showed that there was a significant difference of writing analytical exposition between visual students who were taught by group investigation model and those who were taught by conventional one. There was also a significant difference of writing analytical exposition between auditory students who were taught by group investigation model and those who were taught by conventional one. The data description showed that visual students who were taught by group investigation model obtained higher score of writing analytical exposition. However, there was also an improvement of the writing for auditory students who were taught by group investigation model. So, group investigation was an effective learning model applied in both visual and auditory students. Although visual students obtained better writing achievement than auditory students, it can be concluded that group investigation model was effective for both visual and auditory students at the grade eleventh of SMA Islam Al-Azhar BSD. 
Finally, the result this study showed that there was a significant interaction between group investigation model and learning styles to students' writing of analytical exposition with the significance value of the of 0.019 . Applying group investigation model in teaching writing of analytical exposition developed the students' experience in planning, constructing, revising, and publishing or communicating their writing through investigation. Besides, they also had different way in receiving information. Each student had his/her own style of learning. Although students had the same treatment, they still tended to dominantly apply a certain learning style which was comfortable for them.

The significant interaction means that the use of group investigation model was not the only variable which affected the students' writing of analytical exposition. The students' learning style was also another variable that gave effect to their achievement of writing. Thus, it can be concluded that there was an interaction between group investigation and learning style to students' writing of analytical exposition.

\section{CONCLUSION AND SUGGESTION}

Based on the findings, it can be concluded that applying group investigation model is effective since there was an improvement in the students' writing of analytical exposition. There was a significant difference between the students taught by group investigation model and those taught conventionally on their writing of analytical exposition.

The finding also showed that the visual learners had higher achievement in their writing of analytical exposition. They tended to perform better achievement especially in their writing of analytical exposition than auditory learners. Besides, the visual learners in experimental class had better achievement in their writing. However, comparing to the auditory and visual learners from the controlled class, the auditory and visual learners from experimental class had higher achievement in their writing. Thus, group investigation was still as an effective learning model to be applied for both auditory and visual learners in learning writing of analytical exposition.

Finally, the third finding showed that there was an interaction between group investigation and learning styles to students' writing of analytical 
exposition. The use of group investigation model was not the only variable which affected the students' writing of analytical exposition. The students' learning style was also another variable that gave effect to their achievement of writing.

The findings of this research would be useful for English teachers in applying group investigation model as a viable alternative in teaching writing. The implementation of group investigation model in the writing lesson had been proven to produce positive effects on students' writing achievement.

Since this study only focused on an analytical exposition as the main genre, to see more comprehensive result, further research should involve other kinds of genres, such as narrative texts, report texts, descriptive texts, etc.

Another suggestion is laid on the sample of the participants which was limited to two classes of the second grade students of SMA Islam Al-Azhar BSD. Further research should involve more classes and participants from other institutions to generate more evidence on the effect of group investigation model to the students' writing or to focus on different contexts. In other words, to get more convincing result, the future research should randomly select more students from more schools.

\section{REFERENCES}

Akhand, M., and Hasan, K. (2010). Approaches to Writing in EFL/ESL Context: Balancing Product and Process in Writing Class at Tertiary Level. Journal of NELTA, Vo. 15, No. 1-2, December 2010. Retrieved from Www.nepjol.info/index.php/NE LTA/3823.

Ahmed, O. N. (2012). The Effect of Different Learning Styles on Developing Writing Skills of EFL Saudi Learners. British Journal of Arts and Social Sciences. ISSN: 2046-9578, Vol.5 No.2 (2012) CBritish Journal Publishing, Inc. 2012. Retrieved from http: //www.bjournal.co.uk/ BJASS.aspx.

Brown, H., Douglas. (2007). Principles of Language Learning and Teaching. $5^{\text {th }}$ Edition. New York: Pearson Longman.

Campbell D. T., Stanley J. C. (1963).Experimental and QuasiExperimental Designs for Research. Boston: Houghton Mifflin.

DePorter, Bobby and Hernacki, Mike. (2007). Quantum Learning: 
Membiasakan Belajar Nyaman dan Menyenangkan (Abdurrahman, A., terj.). Bandung: Kaifa.

Ernidawati, T., and Sianturi, O. (2012).Improving Students' Achievement in Writing Analytical Exposition Paragraph through Debate Technique. Retrieved from http: //jurnal.unimed.ac.id/ 2012/ index.php/ jelt/article/ download/369/176.

Felder, R. M., and Spurlin, J. E. (2005).Application, Reliability, and Validity of the Index of Learning Styles. International Journal of Engineering Education.21(1), $\quad 103-$ 112.Retrieved from http: //www4.ncsu.edu/unity/lockers /users/f/felder/public/ILSdir/I LS_Validation(IJEE).pdf.

Harmer, J. (2004).How to Teach Writing.

New York: Pearson Education Limited.

Hung, H. C., and Young, S. S. C. (2015).The Effectiveness of Adopting E-Readers to Facilitate EFL Students' Process-Based Academic Writing. Journal of Educational Technology \& Society, 18 (1), 250-263. Retrieved from http://www.ifets.info/journals/1 8_1/21.pdf.
Isjoni.(2009). Pembelajaran Kooperatif. Pustaka Belajar: Yogyakarta

Nunan. (1998). Language Teaching Methodology: A Tex Book for Teachers. New York: Prentice Hall.

Pasher H., McDaniel M., Rohrer D., and Bjork R. (2009).Learning Styles: Concepts and Evidence. A Journal of the Association for Psychological Science. Volume 9, No. 3, December 2008. Copyright@ 2009. Retrieved from

https://www.psychologicalscien ce.org/journals/pspi/PSPI_9_3.

Pitoyo, A. (2014). The Effect of Group Investigation Learning Model, Accelerated Learning Team and Role Playing on Elementary School Students' Writing Skills Viewed from Cognitive Style. Journal of Education and Practice, Vol 5, No. 2, 2014. Retrieved from www.iiste.org/Journals/index.ph $\mathrm{p} / \mathrm{JEP} / 10871$.

Singh, K., Abdullah, H., Rezaee, A., and Abidin, M. (2011). Learning Styles and Overall Academic Achievement in a Specific Educational System. International Journal of Humanities and Social Science Vol. 1 No. 10; August 2011. Retrieved from http: //www.ijhssnet.com/ 
journals/Vol_1_No_10_August_2 011/19. pdf.

Slavin, Robert E. (2005).Cooperative Learning: Teori, Riset dan Praktek. Bandung: Nusa Media.

Studer, J., R. (2015). The Essential School Counselor in a Engaging Society. Los Angeles/ London/ New Delhi/ Singapore/ Washington DC: Sage Publication Inc.

Sutrisno, Zulaeha, I., and Subyantoro. (2013) Keefektifan Pembelajaran Menulis Karangan Deskriptif dengan Model Quantum dan Inquiri Terpimpin Berpasangan Berdasarkan Gaya Belajar Peserta Didik Sekolah Dasar. Journal of Primary Education. JPE 2 (1) (2013).Retrieved from http://journal.unnes.ac.id/sju/in dex.php/.
Syafini and Rizan, T. N. (2012).The Effects of Cooperative Learning in Enhancing Writing Performance. Bangkok: Universiti Kebangsaan Malaysia. Retrieved from http://www.ukm.my/solls09/ Proceeding/PDF/ Shafini.pdf.

Weigle, S., C. (2002).Assessing Writing. Cambridge: Cambridge University Press.

White, R.V. (1988). Academic Writing: Process and Product. ELT Documents 129. London: Modern English Publications and The British Council. pp. 4-16. 